\title{
Survival and Subsequent Dispersal of Rice Sclerotial Disease Fungi, Rhizoctonia oryzae and Rhizoctonia oryzae-sativae, in Paddy Fields
}

\author{
Qingyuan Guo, Department of Phytopathology, Agricultural College, Xinjiang Agricultural University, No. 42 \\ Nanchang Rd. Urumuqi, Xinjiang 830052, China; Akiko Kamio, Shizuoka Citrus Agricultural Station, 2-12-10 Ko- \\ magoe, Shimizu, Shizuoka 424-0905, Japan; Bhim Sen Sharma, Agricultural Research Station, Rajasthan Agricul- \\ tural University, Durgapura, Jaipur 302018, India; and Yukiko Sagara, Masao Arakawa, and Kimiharu Inagaki, \\ Faculty of Agriculture, Meijo University, Tenpaku, Nagoya 468-8502, Japan
}

\begin{abstract}
Guo, Q., Kamio, A., Sharma, B. S., Sagara, Y., Arakawa, M., and Inagaki, K. 2006. Survival and subsequent dispersal of rice sclerotial disease fungi, Rhizoctonia oryzae and Rhizoctonia oryzaesativae, in paddy fields. Plant Dis. 90:615-622.

In 1998 to 2001, a commercial rice (Oryza sativa) paddy field (area: ca. 0.14 ha) was surveyed for Rhizoctonia oryzae and R. oryzae-sativae, causal agents of bordered sheath spot and brown sclerotium disease of rice plants, respectively, to determine their survival in soil and stubble during the pretransplanting season, and the effect on disease development during the maturation season of rice. Then, infection by these fungi of weeds belonging to 17 families, which grew in the four neighboring fields, was examined during rice growing seasons. All field isolates of the fungi from soil, stubble, rice sclerotial disease lesions (diseased tissues), and weeds were assorted into mycelial compatibility groups (MCGs) based on the barrage zone reaction of paired isolates. In $R$. oryzae, 3 to 8 MCGs were annually found from soil/stubble, 2 to 4 MCGs from rice bordered sheath spot lesions, and 4 to 9 MCGs from 4 to 14 weeds. MCGs common to both soil/stubble and diseased tissues, soil/stubble and weeds, and diseased tissues and weeds numbered 1 to 2 in all cases. In $R$. oryzae-sativae, MCGs common to both soil/stubble and brown sclerotium disease lesions, and soil/stubble and weeds, numbered 1 to 4 and 0 to 5 , respectively. In $R$. oryzae and $R$. oryzae-sativae, a few MCGs were common to soil/stubble, diseased tissues and weeds, and some were also common to diseased tissues in 1998 and soil/stubble in 1999, or weed in 1998 and diseased tissues in 1999. Members belonging to a single MCG from rice diseased tissues were detected from maximally five weeds growing in the neighboring fields. These results indicate that fungi that had caused sclerotial diseases at the maturation stage of rice plants survived on and in soil and stubble until the pretransplanting season of the next year, followed by wide dispersal in and out of fields and by infection and disease development on rice plants and various weeds.
\end{abstract}

Sclerotial diseases of rice (Oryza sativa) caused by Rhizoctonia and Sclerotium species display similar symptoms on the leaf sheaths of the plants. Some of these diseases cause 20 to $35 \%$ yield losses and inferior quality of rice $(7,8,12,25)$. Bordered sheath spot and brown sclerotium disease caused by Rhizoctonia oryzae Ryker et Gooch (Waitea circinata f. sp. oryzae, WAG-O) and $R$. oryzae-sativae (Sawada) Mordue (Ceratobasidium oryzae-sativae Gunnell \& Webster), respectively, occur worldwide in rice growing areas of Southeast Asia, India, Japan, the United States, and Brazil $(2,3,5,6,25)$. In Japan, these two sclerotial diseases occur throughout the rice growing areas $(7,14,16,20)$. Lesions of bordered sheath spot, which are generally produced on leaf

Corresponding author: Kimiharu Inagaki

E-mail: inagakik@ccmfs.meijo-u.ac.jp

Accepted for publication 19 December 2005.

DOI: 10.1094/PD-90-0615

(C) 2006 The American Phytopathological Society sheaths after the heading stage, range in shape from ellipsoid to fusiform and from brown to tan in color with dark brown margins. After the mid-maturation stage, symptoms of brown sclerotium disease occur frequently at the lower part of rice hills, which contain 10 to 20 culms in a sheaf, and usually coalesce with each other and are spherical to fusiform in shape with brown margins $(7,12,21,27)$. Both lesions, especially those of bordered sheath spot, resemble sheath blight caused by $R$. solani AG-1 (IA), but differ markedly from sheath blight lesions by the presence of a broad, dark brown margin.

$R$. oryzae and $R$. oryzae-sativae form sclerotia between leaf sheaths or inside the leaf sheath tissues of rice (19), and the sclerotia persist after harvest (generally September to October in Central Japan) in plant debris, and survive in paddy fields until the following spring. After the transplantation of rice seedlings (May to June), the sclerotia float around within a field until they reach the base of rice hills to begin infection. Weeds growing in and around paddy fields may contribute fungal infection and disease development on rice plants, since the host range of these pathogens includes 14 families and 34 species for $R$. oryzae and 12 families and 47 species for $R$. oryzae-sativae $(15,19)$. The relationship between survival of these pathogens during pretransplanting season and their dispersal during the rice growing season has not been reported for bordered sheath spot and brown sclerotium disease. The objective of this study was to investigate the actual dormancy stage of $R$. oryzae and $R$. oryzae-sativae in paddy fields before the transplanting stage of rice seedlings, and then examine the role of the residues of the pathogens in disease development at the maturation stage. Weeds growing in and around paddy fields were also examined for the presence of the pathogens. Field isolates were grouped based on mycelial compatibility, which was adopted to better understand those relationships as described in previous reports $(9-11,13,23)$.

\section{MATERIALS AND METHODS}

Collection of infected tissues, soil, stubble, and weeds. At the maturation (late September) from 1998 through 2001, lesions caused by $R$. oryzae and $R$. oryzaesativae were collected from rice plants in a paddy field (field B in Fig. 1, area: ca. 0.14 ha) of the experimental farm of Meijo University, Kasugai, Aichi Pref., Central Japan. Forty-two plots were established of $10 \mathrm{~m}$ in length and $5 \mathrm{~m}$ across, and up to 10 diseased lesions were collected per plot, which included 20 to 25 rice hills. In the field, lesions were collected at the same plots each year. At the pretransplanting season (early March), two samples of rice stubble 10 to $15 \mathrm{~cm}$ high, which contained 20 to 30 withered culms and ca. $20 \times 20$ $\mathrm{cm}$ square of surface soil were collected in each plot, desiccated at ca. 10 to $18^{\circ} \mathrm{C}$ for 3 weeks, and stored at $15^{\circ} \mathrm{C}$ until fungal isolation. At the tillering to maturation stage (June to September) in the B field in 1998 and 1999 and the A to E fields in 2000 and 2001, weeds were collected both from within the fields and from the ridges between the fields. In all fields in which the late maturation variety, Aichi-no-kaori, was planted, the sampling of weeds was arbitrary but representative. Field water usually flows from field A to B and from C to $\mathrm{E}$. In a heavy rainy season, it is possible 
for flood water to flow from the A and B fields to the $\mathrm{C}$ to $\mathrm{E}$ fields through the irrigation ditch.

Fungal isolation. The diseased plant tissues, soil, stubble, and weeds were plated on a water-agar medium (WA) in petri dishes ( $9 \mathrm{~cm}$ diameter) that contained $50 \mathrm{ppm}$ streptomycin solution for isolation of $R$. oryzae and $R$. oryzae-sativae. For the diseased tissues, two pieces per sclerotial disease lesion, each ca. $0.5 \mathrm{~cm}$ wide and 1 $\mathrm{cm}$ long, were washed several times in water, disinfected with $1 \%$ sodium hypochlorite for 2 to $3 \mathrm{~min}$, and placed on WA. After 2 to 5 days of incubation at $25^{\circ} \mathrm{C}$, elongated hyphae characteristic of Rhizoctonia species were transferred onto potato sucrose agar (PSA: potato $200 \mathrm{~g}$, sucrose $20 \mathrm{~g}$, agar $20 \mathrm{~g}$, water $1,000 \mathrm{ml}$ ) slants. For stubble, segments of culms 1 to $2 \mathrm{~cm}$ in length were prepared for fungal isolation in the same way as the diseased tissue. Fragments of broken segments were also carefully recovered by use of laterdescribed Tyler's mesh so as not to be lost during washing. One hundred segments were plated from each plot. For soil samples, $200 \mathrm{~g}$ of soil finely crushed with a hammer was put into $500 \mathrm{ml}$ of distilled water in a 1,000-ml Erlenmeyer flask and vigorously stirred for $60 \mathrm{~s}$ with a magnetic stirrer. The supernatant was sieved (Tyler's mesh no. 60: $250 \mu \mathrm{m}$ in diameter) to collect plant debris. Then, putting $500 \mathrm{ml}$ of water into the flask, stirring with the magnetic stirrer, and collection of plant debris were repeated five consecutive times to ensure a thorough collection. One hundred pieces of tissue were used for isolation. For weeds, discolored or brown to dark brown roots and basal parts (within ca. 5 $\mathrm{cm}$ of the soil surface) of plant stems were

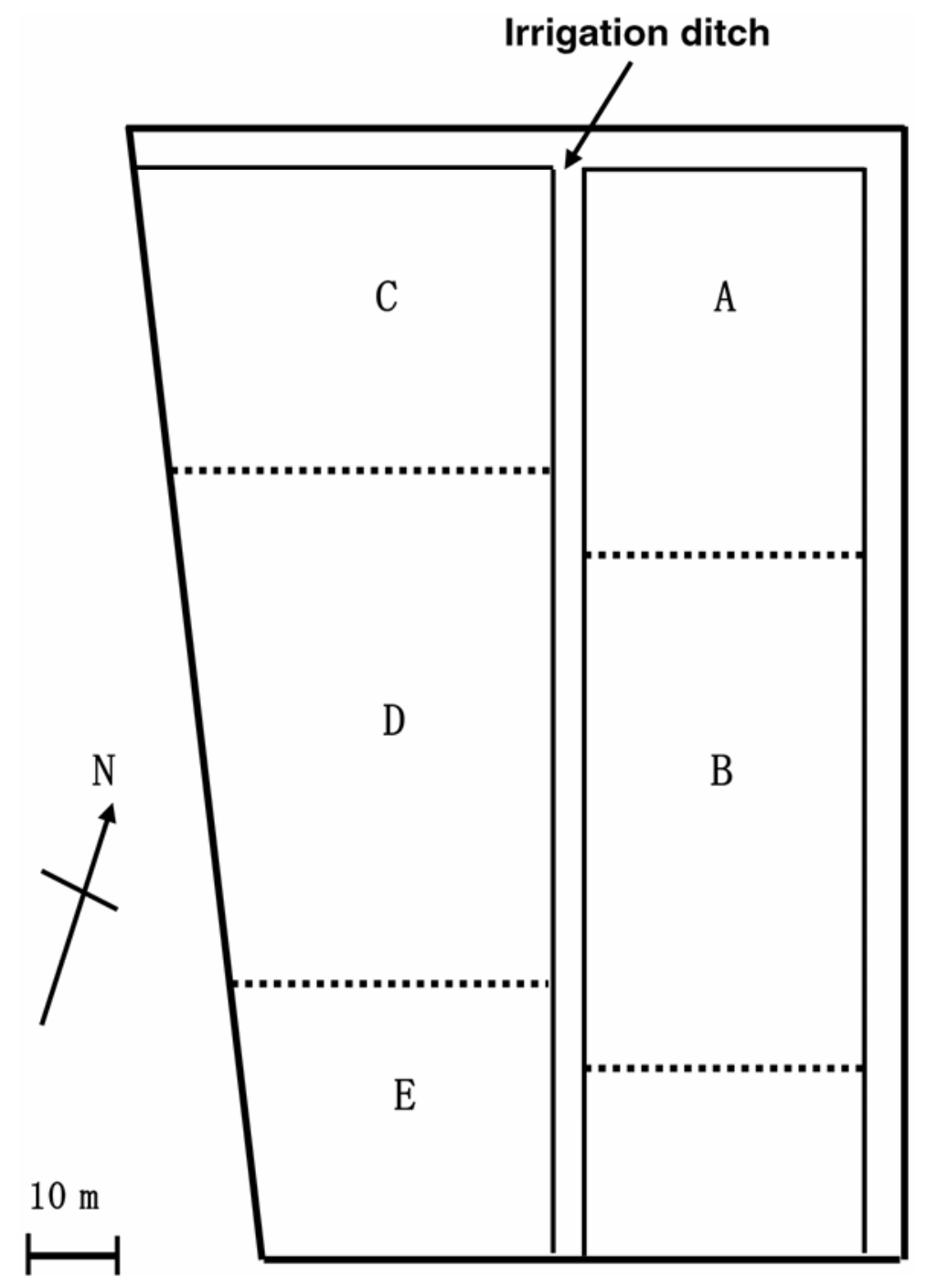

Fig. 1. Spatial arrangement of paddy fields (A, B, C, D, and E) for sampling of three isolation sources, i.e., rice sclerotial disease lesions (diseased tissues), soil/stubble, and weeds. Sampling of diseased tissues and soil/stubble was conducted during the maturation stage (late September) and the pretransplanting season (early March), respectively, in 42 plots which were set up at 5- to $10-\mathrm{m}$ intervals within field $\mathrm{B}$, while weed sampling was conducted during the tillering to maturation stage (June to September) of rice at undetermined plots in field B and its four neighboring fields (A, C, D, and E). Small irrigation ditches (ca. $50 \mathrm{~cm}$ in width) run along the periphery of fields $\mathrm{C}, \mathrm{A}$, and $\mathrm{B}$, and longitudinally between A-B and C-E fields. washed several times in distilled water, and 30 to 50 segments from the tissue of each plant were used for isolation.

Weeds without the above symptoms on the roots and stems were excluded before fungal isolation. For fungal isolation, we used 16 weed species belonging to 9 families in 1998, 20 species in 8 families in 1999, 42 species in 13 families in 2000, and 35 species in 14 families in 2001, for a total of 62 species in 17 families that were composed of 35,9 , and 18 species of annual, biennial, and perennial plants, respectively (22). Weeds from which $R$. oryzae and/or $R$. oryzae-sativae was isolated were individually assigned a number as shown in Table 1.

All field isolates were identified to species based on cultural characteristics, such as color, shape and size of sclerotia, color of colony, mycelial growth rate, and so on, from a 10- to 14-day-old culture grown on PSA slants at $30^{\circ} \mathrm{C}$. Microscopic observation $(\times 400)$ of hyphal fusion between field isolates and tester isolates of the respective pathogens was conducted on WA plates in cases when it was difficult to identify an isolate based on its cultural characteristics. In the observation, isolates showing imperfect fusion (28) with cell death were recognized to belong to the same species as a tester isolate, and isolates showing no hyphal fusion were not excluded.

Determination of mycelial compatibility groups. To determine mycelial compatibility among field isolates, each isolate was grown on a PSA plate at $28^{\circ} \mathrm{C}$ for 3 to 4 days, then five to six mycelial disks (ca. $5 \mathrm{~mm}$ in diameter) from each isolate were placed at 2- to 3-cm intervals on malt extract agar (MEA: malt extract $20 \mathrm{~g}$, peptone $1 \mathrm{~g}$, glucose $20 \mathrm{~g}$, agar $15 \mathrm{~g}$, distilled water $1,000 \mathrm{ml}$ ) in a petri dish. Observations of barrage zone (or interaction zone) formations $(29,30)$ were made after incubation at $28^{\circ} \mathrm{C}$ for 7 to 10 days as previously described (11). Isolates were assigned to the same mycelial compatibility group (MCG) when mycelia from different isolates intermingled at the interface without the formation of a barrage zone, and were assigned to the different groups when a barrage zone was observed. The order of testing isolates for determination of MCGs called strains or isolate groups in the previous studies $(9,10,13)$ was initiated first among plots for the respective isolation source, then among isolation sources and years using one representative isolate within each MCG. MCGs from diseased tissues (bordered sheath spot or brown sclerotium disease lesions), soil/stubble, and weeds were referred to as $\ell, s$, and $w$, respectively, with a serial number of 3 digits, which differed from year to year, e.g., $\ell 802$ in 1998, $\ell 902$ in $1999, \ell 002$ in 2000, and $\ell 102$ in 2001. An MCG that was the same as one detected from another isolation source was referred to as a common MCG, e.g., $\ell$ 803, $s$ 802, and $w 808$ of 
R. oryzae in 1998 (Fig. 2), and was denoted by a dotted line in Figures 2 and 3 . Two replicate MEA plates were used in the above pairing isolates, and the test were repeated two to four times.

\section{RESULTS}

Number of isolates and MCGs. In the B field, bordered sheath spot occurred annually in 3 to 9 plots ( 7 to $21 \%$ ) among the 42 plots $(100 \%)$ surveyed, although it did not necessarily follow that these diseased plots were the same each year, and 27 isolates of $R$. oryzae from bordered sheath spot lesions (diseased tissues) were isolated (Table 2). $R$. oryzae was isolated every year from soil/stubble in 3 to 21 plots (7 to $50 \%$ ), and the total number of isolates from soil/stubble was 155 . The 27 isolates from diseased tissues and 155 from soil/stubble were classified into 12 and 24 MCGs, respectively, each contain- ing four to seven isolates on average. $R$. oryzae was isolated from 19 of the 62 weeds, including 14 annual, 2 biennial, and 3 perennial plants (Table 1). The fungus was isolated from the diseased roots of 14 plants, and from diseased stems of 14 plants. These 19 weeds belonged to seven families: Compositae (II), Gramineae (V), Lythraceae (VI), Plantaginaceae (VII), Polygonaceae (VIII), Pontederiaceae (IX), and Scrophulariaceae (X). The 120 isolates from weeds were classified into 26 MCGs, each containing 2 to 11 isolates (Table 2).

Brown sclerotium disease occurred in 4 to 20 plots (10 to $48 \%$ ) among the 42 in field $\mathrm{B}$, and 116 isolates of $R$. oryzaesativae were recovered (Table 2). The fungus was also isolated from soil/stubble from 13 to 24 plots (31 to $57 \%$ ) annually. A total of 248 isolates were recovered. One-hundred-sixteen isolates from the diseased tissues and 248 from soil/stubble were classified into 44 and 73 MCGs, respectively, each containing two to four isolates on average (Table 2). Weeds with infected stems were 4 compared with 12 weeds with infected roots. This fungus was isolated from 13 weeds, which were composed of 11 annual and 2 perennial species belonging to six families: Commelinaceae (I), Cruciferae (III), Cyperaceae (IV), Gramineae (V), Polygonaceae (VIII), and Pontederiaceae (IX). A total of 93 weed isolates were classified into 27 MCGs.

Common MCGs among isolation sources. Every year from 1998 to 2001, one or two common MCGs of $R$. oryzae were identified from bordered sheath spot lesions (diseased tissues), soil/stubble, and weeds (Fig. 2). MCG $w$ 808, one of the MCGs in common between diseased tissue and weed in 1998, was recovered from Setaria viridis (no. 17) and Persicaria longiseta (no. 22). In 2000, MCG w 004,

Table 1. Isolation of Rhizoctonia oryzae and Rhizoctonia oryzae-sativae from diseased roots ( $\mathrm{r}$ ) and the basal part of stems (s) of weeds growing in field B and the four neighboring paddy fields (A, C, D, and E)

\begin{tabular}{|c|c|c|c|c|c|c|c|c|c|c|}
\hline & \multirow[b]{3}{*}{ Weed $^{\mathrm{a}}$} & \multirow{3}{*}{$\begin{array}{c}\text { Life } \\
\text { cycle }^{b}\end{array}$} & \multicolumn{8}{|c|}{ Isolation result } \\
\hline & & & \multicolumn{4}{|c|}{ Rhizoctonia oryzae } & \multicolumn{4}{|c|}{ Rhizoctonia oryzae-sativae } \\
\hline & & & 1998 & 1999 & 2000 & 2001 & 1998 & 1999 & 2000 & 2001 \\
\hline I & Commelinaceae & & & & & & & & & \\
\hline 1 & Murdannia keisak & An & $-^{\mathrm{c}}$ & & & - & $\mathrm{B}, \mathrm{r}$ & & & - \\
\hline II & Compositae & & & & & & & & & \\
\hline 2 & Eclipta prostrata & An & - & - & $\mathrm{D}, \mathrm{s}, \mathrm{r}$ & $\mathrm{B}, \mathrm{s}, \mathrm{r}$ & - & - & - & - \\
\hline III & Cruciferae & & & & & & & & & \\
\hline 3 & Rorippa islandica & $\mathrm{Pe}$ & & & - & & & & $\mathrm{C}, \mathrm{s}$ & \\
\hline IV & Cyperaceae & & & & & & & & & \\
\hline 4 & Cyperus difformis & An & - & - & - & - & - & $\mathrm{B}, \mathrm{r}$ & $\mathrm{B}, \mathrm{r}$ & - \\
\hline 5 & $\begin{array}{l}\text { Scirpus juncoides var. } \\
\text { ohwiarus }\end{array}$ & An & & - & - & - & & $\mathrm{B}, \mathrm{s}$ & $\mathrm{D}, \mathrm{s}$ & $\mathrm{B}, \mathrm{s}, \mathrm{r}$ \\
\hline V & Gramineae & & & & & & & & & \\
\hline 6 & $\begin{array}{l}\text { Agropyron tsukushiense var. } \\
\text { transiens }\end{array}$ & $\mathrm{Bi}$ & & & $\mathrm{B}, \mathrm{s}$ & & & & - & \\
\hline 7 & Alopecurus aequalis & $\mathrm{Bi}$ & & & $\mathrm{B}, \mathrm{s}$ & - & & & - & - \\
\hline 8 & Digitaria ciliaris & An & $\mathrm{B}, \mathrm{r}$ & & $\mathrm{E}, \mathrm{r}$ & - & $\mathrm{B}, \mathrm{r}$ & & - & - \\
\hline 9 & Digitaria violascens & An & & & $\mathrm{B}, \mathrm{r}$ & - & & & - & - \\
\hline 10 & Echinochloa crus-galli & An & - & & $\mathrm{A}, \mathrm{B}, \mathrm{s}, \mathrm{r}$ & - & _- & & $\mathrm{B}, \mathrm{r}$ & _- \\
\hline 11 & $\begin{array}{l}\text { Echinochloa crus-galli var. } \\
\text { caudata }\end{array}$ & An & - & - & $\mathrm{B}, \mathrm{D}, \mathrm{s}, \mathrm{r}$ & $\mathrm{B}, \mathrm{s}, \mathrm{r}$ & $\mathrm{B}, \mathrm{s}$ & $\mathrm{B}, \mathrm{s}, \mathrm{r}$ & - & $\mathrm{B}, \mathrm{D}, \mathrm{s}, \mathrm{r}$ \\
\hline 12 & $\begin{array}{l}\text { Echinochloa crus-galli var. } \\
\text { formosensis }\end{array}$ & An & & - & $\mathrm{B}, \mathrm{s}, \mathrm{r}$ & - & & - & $\mathrm{A}, \mathrm{r}$ & $\mathrm{A}, \mathrm{r}$ \\
\hline 13 & $\begin{array}{l}\text { Echinochloa crus-galli var. } \\
\text { oryzicola }\end{array}$ & An & & $\mathrm{B}, \mathrm{s}$ & $\mathrm{B}, \mathrm{E}, \mathrm{s}, \mathrm{r}$ & $\mathrm{A}, \mathrm{D}, \mathrm{s}, \mathrm{r}$ & & - & $\mathrm{C}, \mathrm{r}$ & $\mathrm{D}, \mathrm{r}$ \\
\hline 14 & Leptochloa chinensis & An & & & - & - & & & - & $\mathrm{B}, \mathrm{r}$ \\
\hline 15 & Paspalum distichum & $\mathrm{Pe}$ & & & $\mathrm{B}, \mathrm{s}$ & - & & & - & $\mathrm{B}, \mathrm{D}, \mathrm{r}$ \\
\hline 16 & Paspalum thunbergii & $\mathrm{Pe}$ & & - & $\mathrm{B}, \mathrm{s}, \mathrm{r}$ & - & & - & - & - \\
\hline 17 & Setaria viridis & An & $\mathrm{B}, \mathrm{s}$ & & & & - & & & \\
\hline 18 & Setaria glauca & An & & - & $\mathrm{B}, \mathrm{s}, \mathrm{r}$ & & & - & - & \\
\hline VI & Lythraceae & & & & & & & & & \\
\hline 19 & Lythrum anceps & An & $\mathrm{B}, \mathrm{r}$ & & & & - & & & \\
\hline VII & Plantaginaceae & & & & & & & & & \\
\hline 20 & Plantago asiatica & $\mathrm{Pe}$ & & & $\mathrm{B}, \mathrm{s}, \mathrm{r}$ & & & & - & \\
\hline VIII & Polygonaceae & & & & & & & & & \\
\hline 21 & Persicaria hydropiper & An & & $\mathrm{B}, \mathrm{r}$ & & - & & - & & - \\
\hline 22 & Persicaria longiseta & An & $\mathrm{B}, \mathrm{r}$ & $\mathrm{B}, \mathrm{s}$ & $\mathrm{D}, \mathrm{r}$ & - & - & - & - & - \\
\hline 23 & Persicaria thunbergii & An & - & & - & - & $\mathrm{B}, \mathrm{r}$ & & - & - \\
\hline IX & Pontederiaceae & & & & & & & & & \\
\hline 24 & $\begin{array}{l}\text { Monochoria vaginalis var. } \\
\text { plantaginea }\end{array}$ & An & - & & - & $\mathrm{B}, \mathrm{r}$ & - & & $\mathrm{D}, \mathrm{r}$ & $\mathrm{A}, \mathrm{s}, \mathrm{r}$ \\
\hline $\mathrm{X}$ & Scrophulariaceae & & & & & & & & & \\
\hline 25 & Dopatrium junceum & An & & $\mathrm{B}, \mathrm{s}$ & & & & - & & \\
\hline
\end{tabular}

${ }^{a}$ In 1998 and 1999, weeds were collected in field B; in 2000 and 2001 they were collected in field B and the four neighboring paddy fields (A, C, D, E).

${ }^{\mathrm{b}}$ Annual (An), biennial (Bi), or perennial (Pe).

${ }^{\mathrm{c}}$ Rhizoctonia species were not isolated (-) or not sampled (empty cell). r: roots, s: basal parts of plant stems. 
and in 2001, MCG $w$ 101, common MCGs recovered from diseased tissues, soil/ stubble, and weeds were recovered from three to five weeds in fields $\mathrm{A}$ and $\mathrm{D}$, as well as B. Of these two MCGs, MCG $w$ 004 was recovered from Digitaria violascens (no. 9), Echinochloa crus-galli (no. 10), E. crus-galli var. caudata (no. 11), Paspalum thunbergii (no. 16), and Plantago asiatica (no. 20) collected in fields B and D; and MCG $w 101$ was from Eclipta prostrata (no. 2), Echinochloa crus-galli var. caudata (no. 11), and E. crus-galli var. oryzicola (no. 13) in fields A and B. MCG $w$ 006, which was common among diseased tissues, soil/stubble, and weed in 2000, was recovered from five Gramineae (V) weeds, Alopeculus aequalis (no. 7), Echinochloa crus-galli (no. 10), E. crusgalli var. formosensis (no. 12), Paspalum distichum (no. 15), and Setaria glauca (no. 18 ) in field B. MCGs from diseased tissues that were not common to either weed or soil/stubble were 2 in 1998, 2 in 1999, and 1 in 2000 .

As for $R$. oryzae-sativae, 1 to 4 common MCGs were found among the 9 to 25 soil/stubble MCGs and 3 to 17 diseased tissue MCGs each year (Fig. 3). In 2000 and 2001, 1 or 2 common MCGs were found among diseased tissues, soil/stubble, and weeds. Common MCGs between diseased tissues and weeds, such as MCGs $w$

\begin{tabular}{|c|c|c|c|c|}
\hline Year & $\begin{array}{c}\text { Soil/ } \\
\text { Stubble }\end{array}$ & $\begin{array}{l}\text { Diseased } \\
\text { Tissue }\end{array}$ & & Weed \\
\hline 1998 & 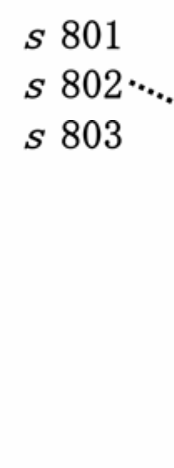 & 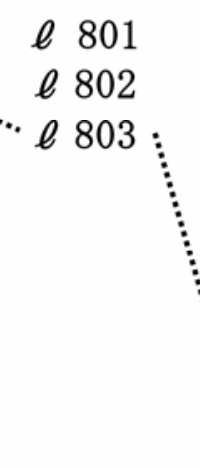 & 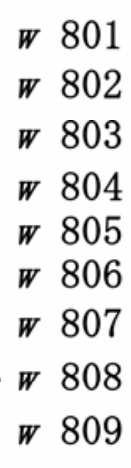 & $\begin{array}{l}(8: \mathrm{B}) \\
(8: \mathrm{B}) \\
(8: \mathrm{B}) \\
(19: \mathrm{B}) \\
(22: \mathrm{B}) \\
(22: \mathrm{B}) \\
(22: \mathrm{B}) \\
(17: \mathrm{B}, 22: \mathrm{B}) \\
(17: \mathrm{B})\end{array}$ \\
\hline 1999 & $\begin{array}{l}s 901 \cdots \\
s 902 \\
s 903 \\
s 904 \\
s 905 \\
s 906 \\
s 907 \\
s 908\end{array}$ & 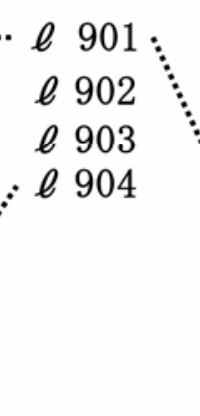 & 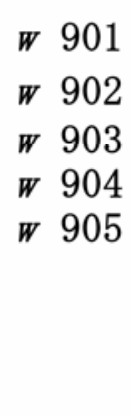 & $\begin{array}{l}(13: B) \\
(25: B) \\
(22: B) \\
(21: B) \\
(13: B)\end{array}$ \\
\hline 2000 & $\begin{array}{ll}s & 001 \\
s & 002 \\
s & 003 \\
s & 004 \\
s & 005 \\
S & 006 \\
s & 007\end{array}$ & 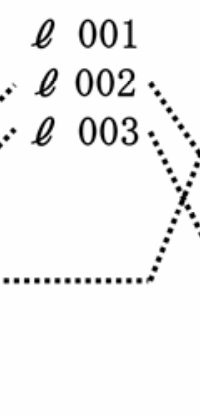 & $\begin{array}{ll}\text { W } & 001 \\
\text { W } & 002 \\
\text { W } & 003 \\
\text { W } & 004 \\
\text { W } & 005 \\
\text { W } & 006 \\
\text { W } & 007 \\
\text { W } & 008\end{array}$ & $\begin{array}{l}(11: B) \\
(10: A, B ; 11: B, 22: D) \\
(11: B, 13: B, 20: B) \\
(9: B, 10: B, 11: D, 16: B, 20: B) \\
(2: D, 12: A, 13: E, D) \\
(7: B, 10: B, 12: B, 15: B, 18: B) \\
(6: B) \\
(8: E)\end{array}$ \\
\hline 2001 & $\begin{array}{ll}s & 101 \cdots \\
s & 102 \cdots \\
s & 103 \\
S & 104 \cdots \\
s & 105 \\
s & 106\end{array}$ & $\begin{array}{ll}\ell & 101 \\
\ell & 102\end{array}$ & $\begin{array}{ll}W & 101 \\
W & 102 \\
W & 103 \\
W & 104\end{array}$ & $\begin{array}{l}(2: B, 11: B, 13: A) \\
(11: B) \\
(24: B) \\
(13: D)\end{array}$ \\
\hline
\end{tabular}

Fig. 2. Common mycelial compatibility groups (MCGs) of Rhizoctonia oryzae among MCGs from bordered sheath spot lesions (diseased tissues: $\ell$ ), soil/stubble $(s)$, and weeds $(w)$. Diseased tissues and soil/stubble were collected in field B, while weeds in numbers corresponding to those in Table 1 were collected in field B and the four neighboring paddy fields, A, C, D, and E. MCGs were shown with numbers of three ciphers, which differed according to years, and common MCGs among $\ell$, $s$, and $w$ MCGs were connected with dotted lines. Numbers in the parentheses behind $w$ MCGs correspond to those shown in Table 1. 
001 and $w 002$ in 2000, and MCG $w 106$ in 2001, were derived from plants collected in fields $\mathrm{C}$ and $\mathrm{D}$, as well as $\mathrm{B}$. The latter MCG, $w 106$ in 2001, was characteristic of a number of the infected plants, i.e., Echi- nochloa crus-galli var. caudata (no. 11), E. crus-galli var. oryzicola (no. 13), Leptochloa chinensis (no. 14), and Paspalum distichum (no. 15), as was also true of MCG $w$ 004 and $w 006$ of R. oryzae in 2000.
Common MCGs between years. Two MCGs of $R$. oryzae and 1 of $R$. oryzaesativae from diseased tissues in 1998 were common to those of the respective fungi from soil/stubble in 1999 (Fig. 4).

\begin{tabular}{|c|c|c|c|c|c|c|}
\hline $\begin{array}{l}\text { Year } \\
1998\end{array}$ & \multicolumn{2}{|c|}{$\begin{array}{c}\text { Soil/ } \\
\text { Stubble }\end{array}$} & \multicolumn{3}{|c|}{$\begin{array}{c}\text { Diseased } \\
\text { Tissue }\end{array}$} & Weed \\
\hline 1998 & 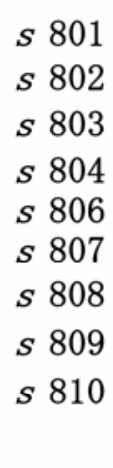 & 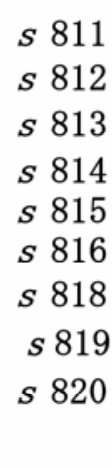 & $\begin{array}{l}s 805 \cdots \\
s \quad 817 \cdot \\
\mathrm{s} 821 \\
s \quad 822 \\
s \quad 823 \\
s \quad 824 \\
s \quad 825\end{array}$ & 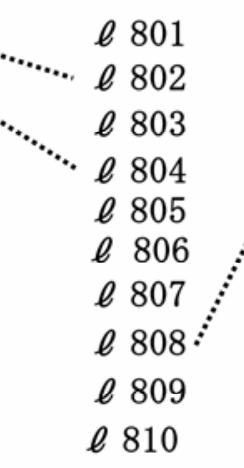 & 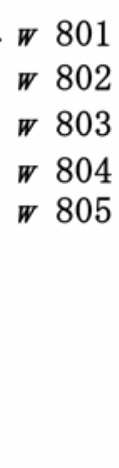 & $\begin{array}{l}(11: B) \\
(11: B, 23: B) \\
(11: B) \\
(1: B) \\
(8: B)\end{array}$ \\
\hline 1999 & & $\begin{array}{l}901 \\
902 \\
903 \\
904 \\
905 \cdots \cdots \\
906 \\
907 \cdot \cdots \cdot . \\
908 \\
909\end{array}$ & & $\begin{array}{llll}\ell & 901 & \ell & 910 \\
\ell & 902 & \ell & 911 \\
\ell & 903 & \ell & 912 \\
\ell & 904 & \ell & 913 \\
\ell & 905 & \ell & 914 \\
\ell & 906 & & \\
\ell & 907 & & \\
\ell & 908 & & \\
\ell & 909 & & \end{array}$ & $\begin{array}{ll}w & 901 \\
W & 902 \\
W & 903\end{array}$ & $\begin{array}{l}(11: B) \\
(4: B) \\
(5: B)\end{array}$ \\
\hline
\end{tabular}

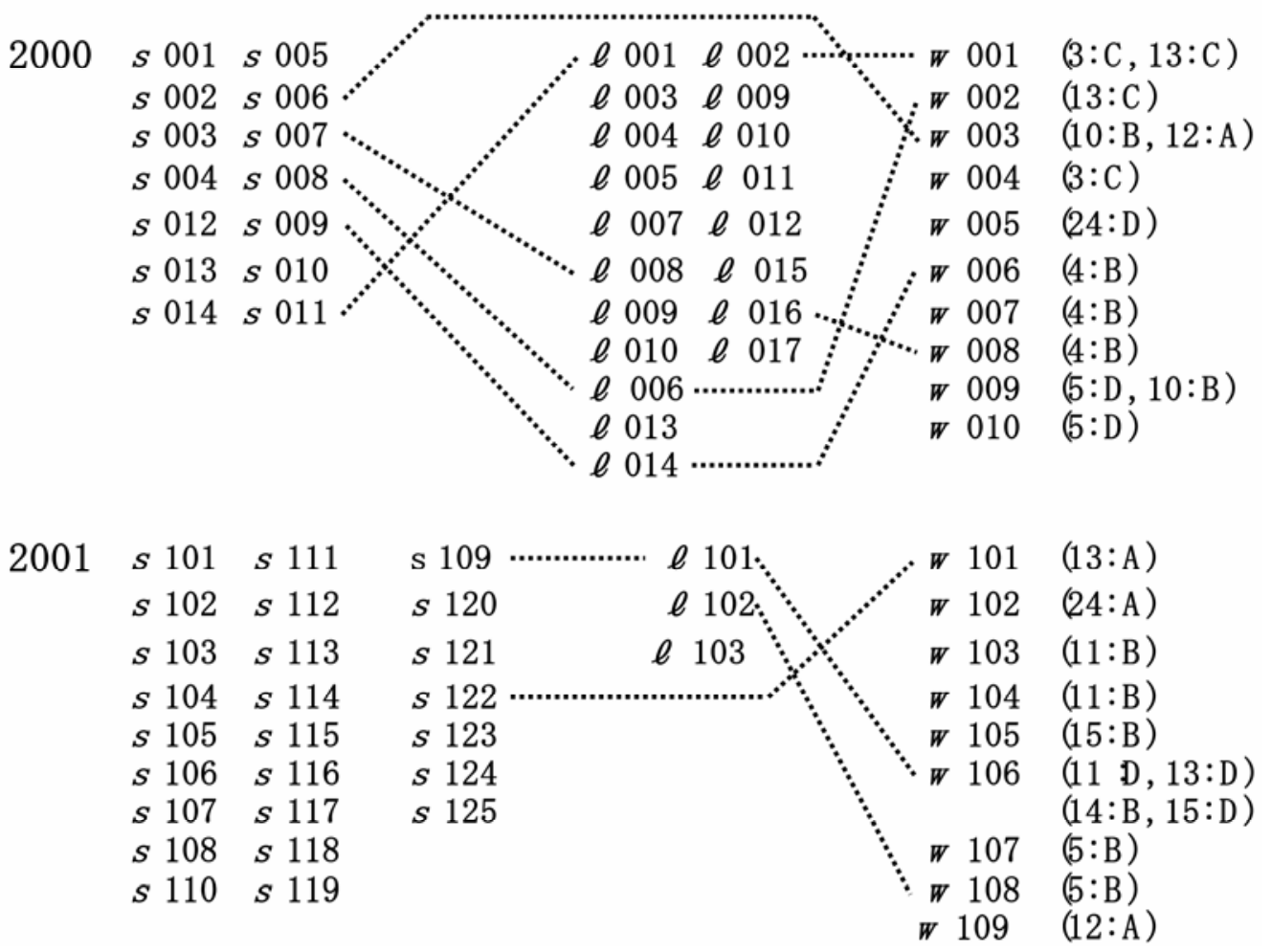

Fig. 3. Common mycelial compatibility groups (MCGs) of Rhizoctonia oryzae-sativae among MCGs from brown sclerotium disease lesions (diseased tissues: $\ell$ ), soil/stubble $(s)$, and weeds $(w)$. Diseased tissues and soil/stubble were collected in field B, while weeds in numbers corresponding to those in Table 1 were collected in field B and the four neighboring paddy fields, A, C, D, and E. Common MCGs among $\ell$, $s$, and $w$ MCGs were connected with dotted lines. See Figure 2. 
One MCG of $R$. oryzae from Setaria viridis (no. 17) and Persicaria longiseta (no. 22) and two of $R$. oryzae-sativae from Echinochloa crus-galli var. caudata (no.
11), P. thunbergii (no. 23), and Murdannia keisak (no. 1) in 1998 were also common to those from diseased tissues in 1999.

\section{DISCUSSION}

Mycelially compatible isolates are genetically related to each other (1). For $R$. solani AG-1 (IA) and AG-2-2 (IV), the

Table 2. Number of isolates and number of mycelial compatibility groups (MCGs) of Rhizcoctonia oryzae and Rhizoctonia oryzae-sativae from sclerotial disease lesions (diseased tissue) of rice plants, soil/stubble, and weeds in paddy fields

\begin{tabular}{|c|c|c|c|c|c|c|c|c|c|c|c|c|c|c|c|c|}
\hline \multirow{2}{*}{$\begin{array}{l}\text { Fungus, } \\
\text { isolation } \\
\text { source }\end{array}$} & \multirow{2}{*}{$\begin{array}{l}\text { Sampling } \\
\text { season }^{\text {a }}\end{array}$} & \multicolumn{3}{|c|}{1998} & \multicolumn{3}{|c|}{1999} & \multicolumn{3}{|c|}{2000} & \multicolumn{3}{|c|}{2001} & \multicolumn{3}{|c|}{ Total } \\
\hline & & Isolate & MCG & IPM $^{\mathbf{b}}$ & Isolate & MCG & IPM & Isolate & MCG & IPM & Isolate & MCG & IPM & Isolate & MCG & IPM \\
\hline \multicolumn{17}{|c|}{ Rhizoctonia oryzae } \\
\hline $\begin{array}{l}\text { Diseased } \\
\text { tissue }\end{array}$ & Late Sept & 3 & 3 & 1.0 & 5 & 4 & 1.3 & 11 & 3 & 3.7 & 8 & 2 & 4.0 & 27 & 12 & $\begin{array}{c}2.3 \\
(3-6)^{c}\end{array}$ \\
\hline $\begin{array}{l}\text { Soil/ } \\
\text { stubble }\end{array}$ & Early March & 6 & 3 & 2.0 & 61 & 8 & 7.6 & 55 & 7 & 7.9 & 33 & 6 & 5.5 & 155 & 24 & $\begin{array}{c}6.5 \\
(1-14)\end{array}$ \\
\hline Weed & June-Sept & 15 & 9 & 1.7 & 9 & 5 & 1.8 & 89 & 8 & 11.1 & 7 & 4 & 2.1 & 120 & 26 & $\begin{array}{c}4.6 \\
(2-11)\end{array}$ \\
\hline Total & & 24 & 15 & - & 75 & 17 & - & 155 & 18 & - & 48 & 12 & - & 302 & 62 & - \\
\hline \multicolumn{17}{|c|}{ Rhizoctonia oryzae-sativae } \\
\hline $\begin{array}{l}\text { Diseased } \\
\text { tissue }\end{array}$ & Late Sept & 26 & 10 & 2.6 & 22 & 14 & 1.6 & 62 & 17 & 3.6 & 6 & 3 & 2.0 & 116 & 44 & $\begin{array}{c}2.6 \\
(1-10)\end{array}$ \\
\hline $\begin{array}{l}\text { Soil/ } \\
\text { stubble }\end{array}$ & Early March & 60 & 25 & 2.4 & 29 & 9 & 3.2 & 47 & 14 & 3.4 & 112 & 25 & 4.5 & 248 & 73 & $\begin{array}{c}3.4 \\
(1-11)\end{array}$ \\
\hline Weed & June-Sept & 18 & 5 & 3.6 & 6 & 3 & 2.0 & 22 & 10 & 2.2 & 47 & 9 & 1.6 & 93 & 27 & $\begin{array}{c}3.4 \\
(1-6)\end{array}$ \\
\hline Total & & 104 & 40 & - & 57 & 26 & - & 131 & 41 & - & 165 & 37 & - & 457 & 144 & - \\
\hline
\end{tabular}

a Sclerotial disease lesions (diseased tissue) and soil/stubble were collected at maturation stage (late September) and the pretransplanting season (early March), respectively, in field B, and weeds at the tillering to maturation stage (June to September), in field B and the four neighboring fields (A, C, D, E).

b Number of isolates per MCG.

${ }^{c}$ Range of the number of isolates.

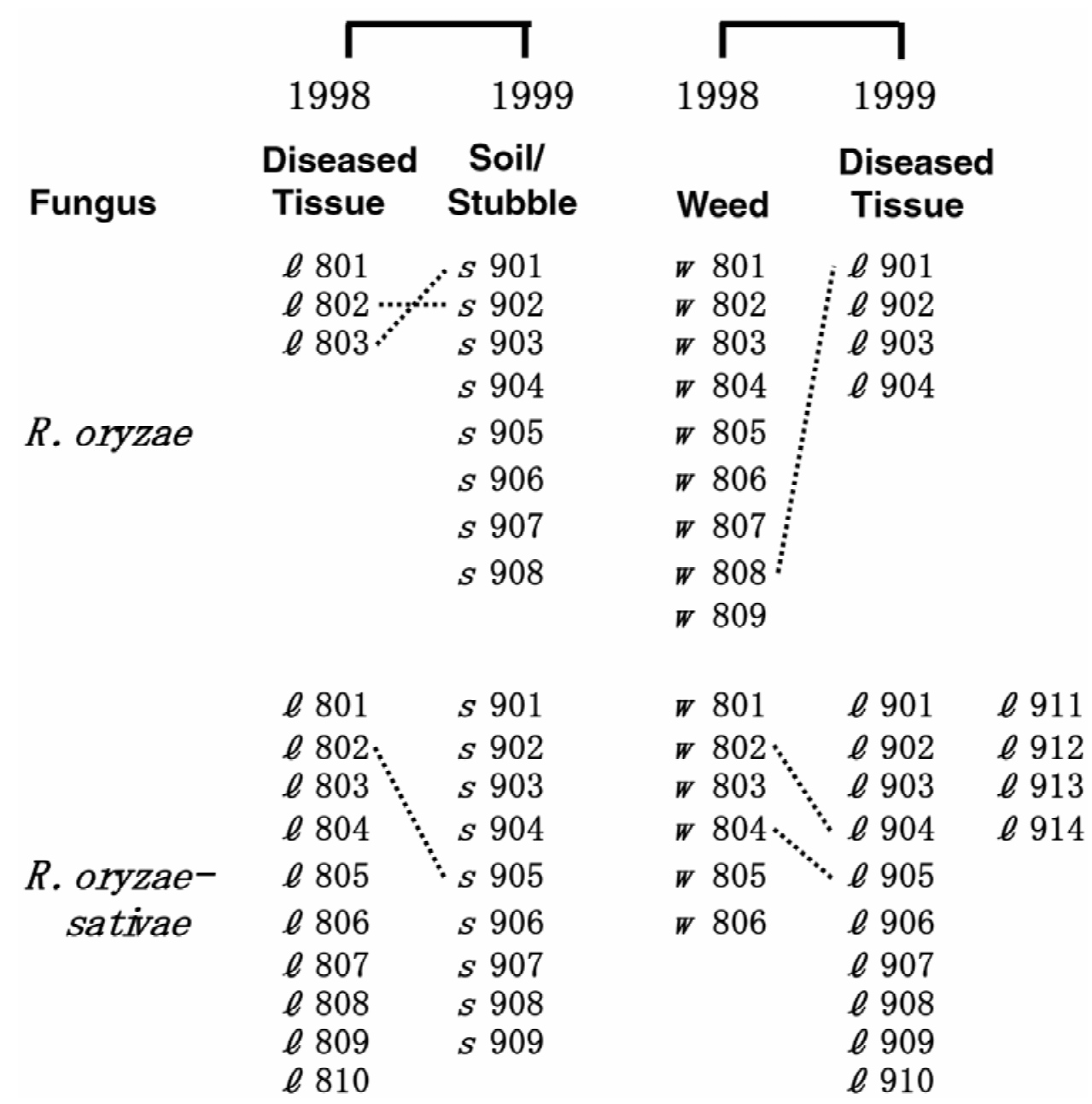

Fig. 4. Common mycelial compatibility groups (MCGs) of Rhizoctonia oryzae and R. oryzae-sativae between 1998 and 1999. Common MCGs among diseases tissues $(\ell)$, soil/stubble $(s)$, and weeds $(w)$ were connected with dotted lines. See Figure 2. 
results of the classification of field isolates on the basis of the MCG almost correspond with those from random amplified polymorphic DNA (RAPD) analysis $(4,17)$. Accordingly, classification of field isolates of $R$. oryzae and $R$. oryzae-sativae, as well as $R$. solani AG-1 (IA), has been applied to better comprehend sclerotial disease occurrences at the maturation stage of rice plants in paddy fields $(9-11,13,23)$. In the present study of $R$. oryzae and $R$. oryzae-sativae, many field isolates and MCGs were obtained from soil/stubble collected at the pretransplanting stage (early March) of rice, although they differed in number according to fungus and year. Then one or two MCGs in R. oryzae and one to four in $R$. oryzae-sativae were annually common to soil/stubble and diseased tissues which were collected at the maturation stage (late September). Moreover, a few MCGs of both fungi were also common to diseased tissues in 1998 and soil/stubble in 1999. These results indicate that soil surface and stubble in paddy fields are important reservoirs of these fungi from the harvest season (mid-October) of the previous year until the following spring, and also serve as primary infection sources of bordered sheath spot and brown sclerotium disease. Our results revealed that not all MCGs that survived at the pretransplanting season within a paddy field caused a sclerotial disease around 6 months later, but some surviving MCGs, differing by year, did so. It has been established in $R$. oryzae that MCGs surviving 2 or more years and causing bordered sheath spot in paddy fields are more highly pathogenic to rice plants than MCGs that survive only 1 year (10), indicating that such highly pathogenic MCGs are capable of survival and dispersal in paddy fields compared to mildly pathogenic MCGs. In the present study, therefore, MCGs, such as $\ell 002$ and $\ell 003$ of $R$. oryzae in 2000 , spreading in neighboring paddy fields and consequently infecting a variety of weeds, are considered to be more highly pathogenic than MCGs such as $\ell 001$ of $R$. oryzae in 2000 that were detected on only one host plant, i.e., rice, and in only one field.

At the pretransplanting stage of rice, it is difficult to evaluate the survival of rice sclerotial disease fungi on weeds because most weeds have not yet developed enough to identify them to the species. Therefore, weeds were collected mainly during the middle to late growth stages of rice. Among the 19 weeds belonging to the 7 families from which $R$. oryzae was isolated, there were 12 new weeds belonging to six families, i.e., no. 2 in Compositae (II), nos. 8, 9, 11, 12, 13, 15, and 16 in Gramineae (V), no. 19 in Lythraceae (VI), no. 21 in Polygonaceae (VIII), no. 24 in Pontederiaceae (IX), and no. 25 in Scrophulariaceae $(\mathrm{X})$, none of which were included in the previous reports on that host range $(15,19)$. In addition, among the 13 weeds belonging to six families from which $R$. oryzae-sativae was isolated, there were nine new weeds belonging to three families, i.e., no. 1 in Commelinaceae (I), nos. 4 and 5 in Cyperaceae (IV), and nos. $10,11,12,13,14$, and 15 in Gramineae (V). In the present study, we mainly focused on fungal infection of weeds in the basal parts of stems and roots, which have been scarcely discussed in view of host range. It is, therefore, possible to assume that the two Rhizoctonia species cause infection and disease development on a wider range of plants than previously reported, although the above new weeds need to be examined for the host range of these species according to Koch's postulates. We proved that $R$. oryzae and $R$. oryzae-sativae that infected weeds in the previous year actually induced diseases in the rice-maturation season of the following year. Gramineae (V) that are ubiquitous in and around paddy fields in the rice growing areas of Japan (22) are considered to be especially important as an infection source of the above two Rhizoctonia species.

Generally, bordered sheath spot and brown sclerotium disease are controlled in the manner used against sheath blight caused by $R$. solani AG-1 (IA), i.e., avoid cultivation with highly nitrogenous manure and apply agricultural chemicals such as varidamycin, flutolanyl, mepronil, and so on $(7,26)$. The fact that a single MCG causing sclerotial disease on rice plants was the same as one infecting up to five species of weeds would make it difficult to effectively control rice sclerotial diseases in paddy fields. Moreover, the added fact that these $w$ MCGs were detected in a number of neighboring paddy fields is also an important factor in making control difficult. Therefore, controlling weeds, especially Gramineae (V), growing within and in the areas bordering paddy fields should be considered in addition to the above traditional methods and cultural practice when attempting to control rice sclerotial diseases $(7,8,18)$. We previously reported that some $\ell$ MCGs spread to close neighboring paddy fields or even to those $200 \mathrm{~m}$ distant to cause the sclerotial disease on rice plants (10). In the present study, $\ell$ MCGs detected in field B were also common to $w$ MCGs in a few neighboring paddy fields infecting various weeds; this is probably due to floating plant debris which contain sclerotia. In addition to sclerotia, basidiospores $(3,24)$ produced on rice plants are possibly dispersed by wind within or beyond paddy fields, but their role in disease development in those fields remains unknown.

\section{ACKNOWLEDGMENTS}

We thank the Agricultural High-Tech Research Center, Meijo University, for financial support and pre-associate professor, Makoto Makino, for useful suggestions.

\section{LITERATURE CITED}

1. Adams, D. H., and Roth, L. F. 1967. Demarcation lines in paired cultures Fomes cajanderi as a basis for detecting genetical distinct mycelia. Can. J. Bot. 45:1582-1589.

2. Gunnell, P. S. 1992. Aggregate sheath spot. Pages 24-25 in: Compendium of Rice Diseases. R. K. Webster and P. S. Gunnell, eds. American Phytopathological Society, St. Paul, MN.

3. Gunnell, P. S., and Webster, R. K. 1987. Ceratobasidium oryzae-sativae sp. nov., the teleomorph of Rhizoctonia oryzae-sativae and Ceratobasidium setariae comb., nov., the probable teleomorph of Rhizoctonia fumigata comb. nov. Mycologia 79:731-736.

4. Hamada, N., Kodama, M., Inagaki, K., and Arakawa, M. 2004. RAPD analysis of Rhizoctonia solani AG-1 (IA) isolates differed in somatic compatibility. 2003. (Abstr.) Ann. Phytopathol. Soc. Jpn. 70:74.

5. Hashioka, Y. 1970. Sheath spots due to sclerotial fungi, Fungal diseases 3. Pages 111-128 in: Rice Diseases in the World VI. Riso, Milano, Italy.

6. Hashioka, Y., and Makino, M. 1969. Rhizoctonia group causing the rice sheath spots in the temperate and tropical regions, with special reference to Pellicularia sasakii and Rhizoctnoia oryzae. Res. Bull. Fac. Agric. Gifu Univ. 28:51-63.

7. Hirayama, S., Kimura, K., Shoji, H., Tanaka, T., and Takeda, T. 1982. Epidemiology and control of brown sclerotium disease and bordered sheath spot of rice plants. Rep. Yamagata Agric. Stn. 16:137-167.

8. Hori, M. 1991. Sheath blight like disease. Pages 145-196 in: Sheath blight of rice plants: Outbreak theory and reality. Japan Plant Prot. Assoc., Tokyo.

9. Inagaki, K. 1990. Relatedness among isolates of Rhizoctonia oryzae Ryker et Gooch causing bordered sheath spot and annual vicissitude of the fungus in paddy fields. Ann. Phytopathol. Soc. Jpn. 56:443-448.

10. Inagaki, K. 1996. Distribution of strains of rice bordered sheath spot fungus, Rhizoctonia oryzae, in paddy fields and their pathogenicity to rice plants. Ann. Phytopathol. Soc. Jpn. 62:386-392.

11. Inagaki, K. 1998. Dispersal of rice sheath blight fungus, Rhizoctonia solani AG-1 (IA), and subsequent disease development in paddy fields, from survey of vegetative compatibility groups. Mycoscience 39:391-397.

12. Inagaki, K. 2001. Outbreaks of rice sclerotium diseases in paddy fields and physiological and ecological characteristics of these causal fungi. Sci. Rep., Fac. Agric., Meijo Univ. 37:57-66.

13. Inagaki, K., and Isomura, Y. 1992. Survival durations of Sclerotium oryzae-sativae Sawada strains in paddy fields and their distribution in a neighboring field. Ann. Phytopathol. Soc. Jpn. 58:340-346.

14. Inagaki, K., and Nakamoto, M. 1982. Occurrence trends of sclerotioses caused by Rhizocto nia oryzae Ryker et Gooch and $3 \mathrm{spp}$. of Sclerotium on rice in the southwestern area of the main island and Nansei-shoto Isles of Japan. Sci. Rep., Fac. Agric., Meijo Univ. 18:20-24.

15. Inagaki, K., Okuda, K., and Makino, M. 1978. Septal structure of hyphae and host range of Rhizoctonia oryzae Ryker et Gooch causing rice sheath spot. Sci. Rep., Fac. Agric., Meijo Univ. 14:1-6.

16. Kadowaki, Y., and Isota, J. 1993. Ecology of sclerotial diseases of rice. Part 1. Seasonal changes in the distribution of sclerotial fungi in paddy fields. Ann. Phytopathol. Soc. Jpn. 59:688-693.

17. Kiyoshi, Y., Kuninaga, S., Naito, S., Akino, S., and Kondo, N. 2002. Differentiation of population of Thanatephorus cucumeris (Rhizoctonia solani AG-2-2-IV) by analysis of RAPD and 
MP-PCR. (Abstr.) Ann. Phytopathol. Soc. Jpn. 68:191.

18. Miller, T. C., and Webster, R. K. 2001. Soil sampling techniques for determining the effect of cultural practices on Rhizoctonia oryzaesativae inoculum in rice field soils. Plant Dis. 85:967-972.

19. Nakata, K., and Kawamura, E. 1939. Studies on rice sclerotial diseases. Mat. Agric. Improv., Agric. For. Min. 139:1-176.

20. Nonaka, F., Tanaka, K., and Sakata, A. 1979. On the several sclerotial fungi isolated from the sheath blight like lesions of rice plants in Japan. Proc. Assoc. Plant Prot. Kyushu 25:3-5.

21. Nonaka, F., Yoshida, M., Yu, C. M., and Tanaka, K. 1982. Seasonal development of sclerotial diseases of rice plants in paddy fields.
Proc. Assoc. Plant Prot. Kyushu 28:18-21.

22. Numata, M., and Yoshizawa, N. 1975. Weed flora of Japan-Illustrated by color. 25-377, Zenkoku Noson Kyoiku Kyokai, Tokyo.

23. Ogoshi, A., and Ui, T. 1983. Diversity of clones within an anastomosis group of Rhizoctonia solani Kuhn in a field. Ann. Phytopathol. Soc. Jpn. 49:239-245.

24. Oniki, M., Ogoshi, A., Araki, T., Sakai, R., and Tanaka, S. 1985. The perfect state of Rhizoctonia oryzae and $R$. zeae, and the anastomosis groups of Waitea circinata. Trans. Mycol. Soc. Jpn. 26:189-198.

25. Ou, S. H. 1984. Fungus disease-Diseases of stem, leaf sheath and root. Pages 247-300 in: Rice Diseases. Commonw. Mycol. Inst., Kew, Surrey, England.
26. Rush, M. C. 1992. Sheath spot. Pages 23-24 in: Compendium of Rice Diseases. R. K. Webster and P. S. Gunnell, eds. American Phytopathological Society, St. Paul, MN.

27. Ryker, T. C., and Gooch, F. S. 1938. Rhizoctonia sheath spot of rice. Phytopathology 28:233-246.

28. Sneh, B., Burpee, L., and Ogoshi, A. 1991 Identification of Rhizoctonia species. American Phytopathological Society, St. Paul, MN. p. 133.

29. Sonoda, R. M., Ogawa, J. M., Essar, T. E., and Manji, B. T. 1982. Mycelial interaction zones among single ascospore isolates of Monilinia fructicola. Mycologia 74:681-683.

30. Worrall, J. J. 1997. Somatic incompatibility in basidiomycetes. Mycologia 89:24-36. 